\title{
Analisis Kualitatif Kecemasan Berkomunikasi Mahasiswa Dengan Dosen Pembimbing Dalam Proses Bimbingan Skripsi
}

\author{
Fatmawati \\ Fakultas Psikologi, Universitas Islam Negeri Ar-Raniry, Banda Aceh \\ Correspondence email: fatmawati@ar-raniry.ac.id
}

\begin{abstract}
Abstrak: Fenomena yang ditemukan sebagai penyebab kecemasan yang dialami mahasiswa tingkat akhir bukan hanya karena kerumitan proses penelitian ilmiah yang akan dihadapi, tetapi juga karena kekhawatiran mahasiswa terhadap dosen yang membimbing serta terhadap metode bimbingan skripsi dosen tersebut. Untuk itu, tujuan dari penelitian ini adalah menganalisis kecemasan berkomunikasi mahasiswa dengan dosen pembimbing dalam proses bimbingan skripsi. Penelitian ini merupakan studi yang menggunakan metodologi kualitatif. Teknik pengumpulan data yang digunakan adalah wawancara mendalam (depth interview) dan observasi. Responden berjumlah 2 orang yang direkrut melalui teknik snowball sampling. Kesimpulan yang dapat diambil adalah responden mengalami kecemasan berkomunikasi dengan dosen pembimbing selama proses bimbingan skripsi. Kecemasan tersebut dikarenakan oleh lack of communication skills and experience, reinforcement, degree of evaluation, subordinate status, dan degree of dissimilarity.
\end{abstract}

Kata kunci: kecemasan berkomunikasi; skripsi; dosen pembimbing; mahasiswa

Abstract: The phenomenon of anxiety experienced by graduate students not only because of the complexity of scientific research process, but also because of worrying to supervisor who guide as well as the methods used by supervisor during thesis guidance. Therefore, the purpose of this study was to analyze students' communication anxiety with the supervisor in the process of thesis guidance. This research was a study using a qualitative methodology. Data collection techniques used were in-depth interviews and observation. The respondents involved were 2 and recruited through snowball sampling technique. The results found that the respondents experienced anxiety when communicated with the supervisor during the thesis guidance. Anxiety is caused by lack of communication skills and experience, reinforcement, degree of evaluation, subordinate status, and degree of dissimilarity.

Keywords: communication anxiety; thesis; supervisor; undergraduate student

\section{PENDAHULUAN}

Skripsi merupakan bukti integritas mahasiswa sebagai wujud implementasi ilmu yang telah diperoleh di perguruan tinggi. Selain itu, skripsi juga menjadi karya tertinggi mahasiswa strata satu yang melibatkan rasa dan karsa serta kemampuan intelijen dan emosional. Karena mereka dituntut tidak hanya memahami teori dan memilih metode penelitian yang tepat, tetapi juga kemampuan untuk menulis secara ilmiah (Puspitasari, 2013). Sebagai bukti integritas serta implementasi teoritis, skripsi bermanfaat untuk memberikan dedikasi kepada masyarakat dengan seluruh ilmu yang diperoleh mahasiswa selama di perguruan tinggi. Manfaat ini juga tercantum dalam tridarma perguruan tinggi yakni pengabdian kepada masyarakat (Lukmantoro, 2000; Liao \& Wong, 2010). Untuk manfaat inilah, proses yang baik dan benar 
adalah kunci keberhasilan skripsi, salah satu diantaranya adalah proses bimbingan skripsi.

Bimbingan skripsi makna dasarnya adalah bimbingan dalam proses skripsi (Silitonga, 2011). Menurut Danim (2003) dan Rosma (2013), beberapa masalah y (c) (i) () g muncul dalam proses pengerjaan skitpri ey lain mahasiswa yang tidak fokus pada judul penelitiannya, bingung terhadap latar belakang masalah, kurang mengerti terhadap teori-teori yang akan digunakan, kurang memahami metodologi penelitian, masalah saat mengumpulkan data, kesulitan dalam menganalisis data, serta kerumitan dalam membahas data secara sistematis dan terstruktur. Semua masalah di atas tidak hanya menguji kecerdasan intelektual mahasiswa, namun juga menguji kecerdasan emosional mahasiswa. Dengan adanya kondisi seperti ini, bimbingan skripsi adalah metode yang tepat untuk mencapai hasil maksimal dan berkualitas dari penelitian ilmiah mahasiswa (Lukmantoro, 2000; Silitonga, 2011, Rosma, 2013).

Berhasil atau tidaknya skripsi adalah tanggung jawab dari mahasiswa yang melakukan penelitian tersebut. Namun, keberhasilan skripsi juga dipengaruhi oleh lingkungan mahasiswa. Ketika motivasi internal mahasiswa dalam proses penyusunan skripsi menurun, motivasi eksternal dari lingkungan sangat dibutuhkan. Dosen pembimbing skripsi adalah bagian dari lingkungan mahasiswa tersebut. Dengan kata lain, keberhasilan skripsi juga merupakan tanggung jawab dosen pembimbing yang juga adalah utusan dari perguruan tinggi agar secara langsung membimbing mahasiswa.

Dosen pembimbing skripsi mempunyai peran membimbing mahasiswa agar mahasiswa memahami etika penelitian ilmiah terutama yang menyangkut plagiarisme dan sikap ilmiah, menetapkan masalah penelitian, menelusuri literatur, menyusun usul penelitian, mampu menerapkan teknik presentasi yang baik, mampu menulis skripsi, dan mampu melakukan ujian lisan saat mempertanggungjawabkan hasil pengerjaan skripsinya di hadapan dosen penguji. Oleh sebab itu, peranan dosen pembimbing saat bimbingan skripsi sangatlah penting dalam mendukung mahasiswa dalam penelitian dan proses pengerjaan skripsinya. Melalui bimbingan skripsi, dosen pembimbing skripsi bertanggung jawab untuk membimbing mahasiswa sehingga mahasiswa mengerti etika penelitian ilmiah, tidak mengalami tekanan mental dalam proses penelitian dan penyelesaian skripsi, serta menghasilkan skripsi yang berkualitas dan bermanfaat bagi masyarakat (Silitonga, 2011).

Meskipun demikian, Lukmantoro (2000) menyebutkan bahwa fenomena yang ditemukan sebagai penyebab kecemasan yang dialami mahasiswa tingkat akhir bukan hanya karena kerumitan proses penelitian ilmiah yang akan dihadapi, tetapi juga karena kekhawatiran mahasiswa terhadap dosen yang membimbing serta terhadap metode bimbingan skripsi dosen tersebut. Mahasiswa mengalami kecemasan terhadap karakter dosen yang akan membimbing mereka. Mahasiswa mengharapkan untuk dibimbing oleh dosen tertentu yang sesuai dengan karakternya dan merasa cemas jika mendapatkan dosen pembimbing yang di kalangan mahasiswa telah mendapatkan label 'kejam, kaku, perfeksionis, sangat mendominasi, dan banyak permintaan'.

Kecemasan yang semakin meningkat dapat menghambat komunikasi dosen pembimbing dan mahasiswa dalam bimbingan skripsi (Puspitawati, 2013; Huerta, Goodson, Beigi \& Chlup, 2016). Interaksi dosen pembimbing dengan mahasiswa dalam bimbingan skripsi memerlukan peranan komunikasi yang dapat mempengaruhi kognitif, afektif, dan perilaku mahasiswa dalam menyelesaikan skripsinya (DeVito, 2012). Peranan dosen pembimbing diharapkan mampu mengurangi permasalahan yang akan dialami mahasiswa dalam proses pengerjaan skripsi, namun terdapat kondisi nyata dimana dosen pembimbing skripsi menjadi salah satu permasalahan bagi mahasiswa dalam proses pengerjaan skripsinya. Mahasiswa merasa khawatir bila akan bertemu dengan dosen pembimbing dan mengalami kecemasan berkomunikasi saat bimbingan skripsi.

Berdasarkan latar belakang masalah di atas, maka peneliti tertarik untuk meneliti kecemasan berkomunikasi mahasiswa dengan dosen pembimbing dalam proses bimbingan skripsi. Adapun tujuan penelitian ini antara lain adalah untuk (1) Mengetahui kecemasan berkomunikasi mahasiswa dalam pengalaman interaksi komunikasi dengan dosen pembimbing dalam proses bimbingan skripsi. (2) Mengetahui faktor-faktor yang berpotensi menjadi penyebab terjadinya kecemasan mahasiswa dalam interaksi komunikasi dengan dosen pembimbing dalam proses bimbingan skripsi. 


\section{METODE}

Penelitian mengenai kecemasan berkomunikasi antara mahasiswa dengan dosen pembimbing dalam proses bimbingan skripsi ini merupakan studi yang menggunakan metodologi kualitatif. Pendekatan kualitatif yang sangat sesuai adalah pendekatan kualitatif berjenis fenomenologi. Prosedur pengambilan responden dilakukan dengan teknik snowball sampling yaitu peneliti dapat berinteraksi dengan sejumlah partisipan yang potensial. Dalam penelitian ini jumlah responden yang bersedia berjumlah 2 orang yaitu ZA dan HD.

Penelitian ini dilakukan di Program Studi Psikologi Universitas Syiah Kuala. Pemilihan lokasi ini dikarenakan pada program studi inilah ditemukan beberapa kasus kecemasan mahasiswa dalam interaksi komunikasi dengan dosen dalam bimbingan skripsi. Teknik pengumpulan data yang digunakan antara lain wawancara mendalam (depth interview) dan observasi.

\section{HASIL DAN PEMBAHASAN}

Analisis data dilakukan berdasarkan pengelompokkan yang mengacu pada faktorfaktor yang mempengaruhi kecemasan berkomunikasi dengan memberikan kode, yaitu HD (responden pertama), ZA (responden kedua), $\mathrm{W}$ (wawancara), dan b (baris) pada lampiran yang dipaparkan sebagai berikut:

\section{a. Degree of Dissimilarity}

HD maupun ZA pernah mengalami perbedaan pendapat dengan dosen pembimbing yang mampu memunculkan kecemasan pada mereka. Meskipun demikian, HD masih mampu mengungkapkan idenya dengan baik sehingga perbedaan pendapat dengan dosen pembimbing dapat teratasi dengan baik. Hal tersebut dapat dilihat dari hasil wawancara berikut ini:

"Kesulitannya itu ya... kadang-kadang kan, kalo misalnya beda gitu kan kak kan, dosennya maunya gini, kita maunya gitu, maunya gini gitu. Misalnya pas penentuan sampel itu, sampel misalnya gini, dari beberapa saran sampelnya itu, sampelnya itu rupanya banyak, sekitar tiga ratus orang, dan kita sebagai mahasiswa kan maksudnya ada juga keterbatasan tenaga, apa ini, segala macem, dan pengennya itu sampelnya lebih sedikit dari itu, takutnya tu ya disitu... apa ada gapnya, tapi setelah dikomunikasiin ya berjalan dengan baik aja sih sebenernya." (Lampiran 3.HD.W1./b.150-161)

Sama halnya dengan HD, ZA juga pernah mengalami perbedaan pendapat dengan dosen pembimbing. Namun, untuk mereduksi kecemasan akibat perbedaan pendapat tersebut, ZA membuktikan argumentasinya dengan mencari sumber literatur lainnya yang kemudian disampaikan kepada dosen pembimbing. Hal tersebut dapat dilihat dari hasil wawancara berikut ini:

"Berbeda pendapat itu waktu ide pertama, kenapa ini teliti ini, abis itu waktu kedua gak ada lagi." (Lampiran 3.ZA.W1./b.272-273)

"Karena kemaren disuruh baca dulu, disuruh cari dulu, jadi saya balek cari itu dulu. Waktu dikasih...betol memang banyak berpengaruh, teliti aja dibilang." (Lampiran 3.ZA.W1./b.276-279)

\section{b. Reinforcement}

Kecemasan berkomunikasi lainnya yang juga dialami oleh HD dan ZA adalah adanya reinforcement negatif yang diperoleh dari dosen pembimbing selama proses bimbingan yang berupa penolakan dan mempertahankan ide. HD menyebutkan bahwa ia mengalami kesulitan dalam menyampaikan pendapat saat dosen pembimbing menanyakan dasar pemikirannya dalam pemilihan judul. Hal tersebut dapat dilihat dari hasil wawancara berikut ini:

"Pas awalnya tuh juga... tetap ya... apa ya maksudnya, konsep-konsep logika berpikir itu yang ditanyain pertama, abis tu gimana kita buat latar belakang, kenapa sih masalah ini yang harus diangkat, kenapa subjeknya harus ini segala macem. Dan itu kan membutuhkan argumentasi. Selain itu juga, data-data yang mendukung, dan ketika data yang mendukung itu sedikit, itulah sebenernya yang membuat kita itu sulit gitu untuk mempertahankan." (Lampiran 3.HD.W1./b.94-102)

Hal yang sama juga dialami oleh ZA, ia merasa cemas jika mendapatkan penolakan dari 
dosen pembimbing. Hal tersebut dapat dilihat dari hasil wawancara berikut ini:

"Cemas sih, takut ini ditolak lagi, takut itu pertama.. kan ini gak bisa ini."

(Lampiran 3.ZA.W1./b.117-118)

Akibat ketakutan akan penolakan tersebut, ZA melakukan keinginan yang diminta oleh dosen pembimbing kedua untuk melakukan wawancara awal, padahal ZA tidak mengerti proses untuk melakukan wawancara tersebut. Hal tersebut dapat dilihat dari hasil wawancara berikut ini:

"Yang paling cemas itu waktu disuruh wawancara, karena disuruh cari data wawancara, dan saya gak tau, maksudnya wawancara ini kekmana." (Lampiran 3.HD.W1./b.298-300)

\section{c. Degree of Evaluation}

Kecemasan berkomunikasi lainnya yang juga muncul pada HD dan ZA adalah ketika dosen pembimbing banyak mengajukan pertanyaan selama proses bimbingan. Menurut penjelasan dari $\mathrm{HD}$, terdapat beberapa pertanyaan dari dosen pembimbing yang tidak mampu ia jawab dan membuatnya merasa malu untuk menjumpai dosen pembimbingnya kembali. Hal tersebut dapat dilihat dari hasil wawancara berikut ini:

"Abis itu kadang-kadang kalo dosennya tanya, kita gak tau itu sampe, sampe apa ya... terdiam sendiri atau ya ya aja, kek gitu kak. Terus ngerasa malu, kek gitu.. ada juga pernah muncul perasaanperasaan kek gitu, terlebih ya pas, pas apa ya, pas ekspektasi itu terhadap kita gak... gak apa ya.. gak mampu kita wujudkan, kek gitulah ataupun kita misalnya ibu tu berharap kita berargumentasi yang seperti ini, rupanya kita argumentasinya lemah kek gitu, itu kan membuat kita ya... bodoh kali ya.. kita rasa ini, kek gitu. Membuat malu juga jumpa ibu, tapi apa boleh buat lah." (Lampiran 3.HD.W1./b.553-565)

Berbeda halnya dengan HD, ZA tidak merasakan adanya kecemasan saat dosen pembimbing mengajukan pertanyaan kepadanya. Hal tersebut dapat dilihat dari hasil wawancara berikut ini:

"Ditanya ada lah ditanya, karena kita baru pertama dan gak ngerti ditanya ini, kenapa ambil itu, ditanya... saya jawab semana kita tahu, kektu saya jawab.. ini dah ini.. ni.. kita baca ini, kektu jawab, kekmana yang ini, yang kita ngerti." (Lampiran 3.ZA.W1./b.59-63)

\section{d. Subordinate Status}

HD juga mengalami kecemasan berkomunikasi saat ia merasa pengetahuan dosen lebih tinggi daripada dirinya. Selain itu, dosen pembimbing juga menuntut HD untuk mencari sumber informasi yang lebih banyak berkenaan dengan judul skripsinya, baik jurnal, buku, ataupun sumber elektronik lainnya. Hal tersebut dapat dilihat dari hasil wawancara berikut ini:

"Heeemm, ada juga, itu juga pernah terjadi, apalagi ini, apalagi lagi buat bab satu, latar belakang itu banyak ni, banyak mau dosennya, harus banyak dapet hasil penelitian ini, ini, ini... kadang-kadang waktu kita dituntut untuk cari data seperti ini, itu gak nemu kita kak, kita kadangkadang pusing sendiri, darimana kita bisa, dimana kita bisa dapetin ini, udah cari diinternet, tapi gak ada gitu, itu sebenernya yang... yang buat apa ya.. pusinglah kek gitu, karena...karena ya tuntutan dan dosennya kek gitu, sedangkan kita agak susah nyarinya kek gitu." (Lampiran 3.HD.W1./b.202-212)

ZA juga mengalami hal yang sama saat dosen pembimbing menuntut sesuatu darinya. Namun, ZA lebih memilih untuk diam saja tanpa membantah apa yang dikatakan oleh dosen pembimbing. Hal tersebut dapat dilihat dari hasil wawancara berikut ini:

"Iya kamu harus kekgini, iya aja di depan dosen, jangan dia marah." (Lampiran 3.HD.W1./b.146-147)

\section{e. Lack of communication skill and experience}

Sumber kecemasan lainnya yang juga dirasakan oleh HD adalah kurangnya keterampilan berkomunikasi sehingga ide yang diutarakan oleh HD terkadang berbeda dengan apa yang diinginkannya. Hal tersebut dapat dilihat dari hasil wawancara berikut ini:

"Itulah kan, kadang-kadang kita tau dalam pikiran kita tu kek gini, tapi pas ngungkapin kok jadi melenceng gitu. Kalo jujur, dosen pembimbingnya juga gak nangkep maksudnya apa, ngomong apa... nah itu. tu gara-gara cemas." (Lampiran 3.HD.W1./b.250-254)

Berbeda halnya dengan yang dialami oleh ZA. ZA tidak merasa cemas saat berkomunikasi 
dengan dosen pembimbing satu, tetapi kecemasan tersebut muncul saat bertemu dengan dosen pembimbing kedua. Kecemasan yang terjadi pada ZA menyebabkan ia tidak berani untuk menjumpai dosen pembimbingnya secara langsung, melainkan melalui sms. Hal tersebut dapat dilihat dari hasil wawancara berikut ini:

"Udah duduk saya di depan itu, terus sms balek, "bu saya boleh ketemu gak", dibilang sama... dibilang sama ibu tu, "coba baca balek smsnya, kapan kemaren bilang ketemu”. Kan itu udah marah kan, gak enak juga kan, emang pas sebenernya setengah dua, emang setengah dua, karena ibu tu duluan, gak... gak telat saya." (Lampiran 3.ZA.W1./b.173-179)

Hasil penelitian menunjukkan bahwa kecemasan berkomunikasi yang dialami oleh responden berbeda-beda. Hal ini dapat dilihat berdasarkan faktor-faktor yang mempengaruhi kecemasan berkomunikasi dari Powell dan Powell (2010) yaitu dan DeVito (2012).

HD mengalami kecemasan akibat terjadinya perbedaan pendapat dengan dosen pembimbing dimana HD harus berusaha untuk menyesuaikan pendapatnya tersebut dengan keinginan dosen pembimbing. Ketidaksesuaian pendapat ini merupakan bagian dari faktor degree of dissimilarity. Powell dan Powell (2011) menyebutkan bahwa saat seseorang merasakan sedikit persamaan, maka kecemasan berkomunikasi akan terjadi. Meskipun demikian, HD memiliki cara penyampaian pendapat yang baik, sehingga dosen pembimbing mampu menerima dan perbedaan pendapat dapat teratasi. Hal ini sesuai dengan yang disampaikan oleh bahwa Lukmantoro (2000) ketika seseorang mampu melakukan komunikasi secara tepat dengan lawan bicaranya, maka kesalahpahaman informasi dapat dihindari. Sama halnya dengan $\mathrm{HD}, \mathrm{ZA}$ juga mengalami kecemasan dikarenakan perbedaan pendapat dengan dosen pembimbing. Namun, ZA melakukan cara yang berbeda untuk mereduksi kecemasannya tersebut, yaitu dengan mencari berbagai sumber informasi yang mendukung argumentasinya.

Faktor lainnya yang menimbulkan kecemasan selama proses bimbingan skripsi adalah pemberian reinforcement yang negatif dari dosen pembimbing. HD menyebutkan bahwa ia mendapatkan reinforcement yang negatif dari dosen pembimbing selama proses bimbingan berupa penolakan ide, begitu pula yang dialami oleh ZA. Sellnow (2005) menjelaskan bahwa reinforcement adalah proses belajar dimana individu yang belajar mengembangkan komunikasi akan dapat mengurangi kecemasan komunikasi dibandingkan individu yang tidak belajar untuk mengembangkan komunikasi yang akan dilakukan. Penolakan yang diberikan oleh dosen pembimbing membuat mahasiswa untuk mengutarakan idenya sehingga muncullah kecemasan berkomunikasi.

Sikap dosen pembimbing yang banyak mengajukan pertanyaan semasa proses bimbingan juga membuat $\mathrm{HD}$ mengalami kecemasan. Berbeda halnya dengan ZA yang merasa mampu menjawab pertanyaan yang diajukan oleh dosen pembimbing sehingga ia tidak merasa cemas. HD bahkan sampai merasa malu jika ia terkadang tidak mampu menjawab pertanyaan yang diajukan oleh dosen pembimbing. DeVito (2011) menyatakan bahwa kecemasan akibat degree of evaluation akan muncul apabila seseorang merasa dirinya sedang dievaluasi. Selain itu, Silitonga (2011) juga menambahkan bahwa jika seseorang tidak mampu memenuhi ekspeksi yang diharapkan oleh lingkungannya, maka ia akan merasa kecewa hingga menyalahkan dirinya sendiri.

Penyebab kecemasan lainnya yang dirasakan oleh HD dan juga ZA adalah sikap dosen pembimbing yang memaksakan kehendaknya kepada mahasiswa. Pemaksaan yang dilakukan oleh dosen pembimbing kepada HD berupa permintaan untuk mencari sumber data yang lebih spesifik untuk memperkuat kerangka berpikir HD terhadap skripsinya. Namun, HD mengatakan bahwa ia mengalami kesulitan untuk menemukan sumber informasi tersebut dikarenakan literatur di bidang kajian HD masih sangat terbatas. Begitu pula halnya yang terjadi pada ZA. Menanggapi sikap dosen pembimbing yang demikian, ZA lebih memilih untuk diam dan tidak membantah terhadap apa yang dikatakan oleh dosen pembimbingnya tersebut. Pemaksaan kehendak yang dilakukan oleh dosen pembimbing merupakan bagian dari faktor subordinate status. DeVito (2012) menyebutkan bahwa ketika seseorang mempunyai pengetahuan lebih luas darinya dan mengekspektasi orang lain untuk memiliki hal yang sama, maka kecemasan berkomunikasi akan semakin meningkat. Pengetahuan luas yang dimiliki oleh seorang dosen terkadang memaksa mahasiswanya untuk mengetahui lebih daripada dosennya tersebut, sehingga terkesan 
memaksakan kehendak kepada mahasiswa, misalnya dengan membaca literatur yang lebih banyak untuk memperkuat landasan bepikir mahasiswa dalam menyusun skripsi.

Hal lainnya yang juga menjadi sumber penting sebagai penyebab munculnya kecemasan dalam proses bimbingan skripsi adalah lack of communication skill and experience. HD mengakui bahwa kurangnya keterampilan dalam berkomunikasi menyebabkan ide yang diutarakan oleh HD terkadang berbeda dengan apa yang diinginkannya, sehingga dosen pembimbing merasa kebingungan untuk memahami pernyataan yang disampaikan oleh HD. Berbeda halnya dengan HD, ZA lebih memilih untuk mengirimkan pesan singkat melalui telepon genggam kepada dosen pembimbingnya walaupun ia telah melihat dosen pembimbingnya berada di kampus. Perilaku demikian ia lakukan untuk mereduksi kecemasan yang dialami oleh ZA. Hal tersebut sesuai dengan yang dikatakan oleh Powell dan Powell (2011) bahwa kecemasan individu dipengaruhi oleh keberhasilan individu mengembangan keterampilan dalam komunikasi. Jika individu gagal dalam mengembangkan keterampilannya, maka kecemasan berkomunikasi akan muncul dan akan berakibat pada komunikasi interpersonal.

\section{SIMPULAN DAN SARAN}

Kesimpulan yang dapat diambil dari pembahasan ini adalah responden mengalami kecemasan berkomunikasi dengan dosen pembimbing selama proses bimbingan skripsi. Kecemasan tersebut dikarenakan oleh lack of communication skills and experience, reinforcement, degree of evaluation, subordinate status, dan degree of dissimilarity. Lack of communication skills and experience terjadi karena responden tidak memiliki keterampilan komunikasi yang baik, sedangkan kecemasan akibat reinforcement terjadi karena adanya reinforcement yang negatif dari dosen pembimbing berupa penolakan ide. Degree of evaluation adalah faktor munculnya kecemasan akibat perasaan dievalusi oleh dosen pembimbing, subordinate status merupakan sikap dosen pembimbing yang memaksakan kehendaknya sehingga mahasiswa menjadi cemas karena tidak mampu menolak, dan degree of dissimilarity merupakan faktor penyebab kecemasan yan terjadi karena adanya perbedaan pendapat dengan dosen pembimbing.

Akibat kecemasan tersebut, responden melakukan penarikan diri dan ketidaknyamanan internal. Penarikan diri dilakukan oleh responden dengan menghindar untuk bertemu dengan dosen pembimbing, sedangkan ketidaknyamanan internal ditunjukkan dengan perasaan gelisah dan tidak nyaman saat sedang dalam proses bimbingan dengan dosen pembimbing.

Berdasarkan kesimpulan di atas, maka peneliti perlu mengajukan beberapa saran, yaitu:

1. Bagi mahasiswa

a. Hendaknya terbuka untuk menyesuaikan diri dengan karakter dosen pembimbingnya dalam interaksi komunikasi dengan dosen pembimbing, tidak terlalu fokus pada pemikiran dan ketakutannya terhadap dosen pembimbing dalam bimbingan skripsi, serta turut merasakan perasaan dan kondisi pembimbing saat hendak bimbingan.

b. Hendaknya mahasiswa tidak fokus pada kecemasan akan karakter dosen pembimbingnya dan berpikiran positif terhadap pembimbingnya karena bagaimanapun karakter dosen pembimbing jika melihat mahasiswa bimbingannya sungguh-sungguh dalam mengerjakan skripsinya, setiap dosen pembimbing akan terbuka untuk memahami dan mendukung mahasiswa bimbingannya dalam menyelesaikan skripsi sebaik-baiknya.

2. Bagi dosen pembimbing

a. Hendaknya mampu menerapkan suasana bimbingan yang konsusif, seperti memberikan kesempatan kepada mahasiswa untuk mengungkapkan idenya serta menyampaikan apresiasi atas keberanian mahasiswa dalam mempertahankan idenya di hadapan dosen pembimbing.

b. Hendaknya mampu melihat secara implisit kemampuan yang dimiliki oleh mahasiswa sehingga dosen pembimbing dapat terus memberikan dukungan dan motivasi agar mahasiswa dapat menyelesaikan skripsinya dengan hasil yang optimal.

\section{DAFTAR RUJUKAN}

Danim, P. (2003). Riset Keperawatan Sejarah dan Metodologi. Jakarta: EGC. 
DeVito, J.A. (2001). The Interpesonal Communication Book. New York: Addison Wesley Longman Inc.

Huerta, M., Goodson, P., Beigi, M., \& Chlup, D. (2016). Graduate students as academic writers: Writing anxiety, self-efficacy and emotional intelligence. Higher Education Research \& Development, 114.

Liao, M. T., \& Wong, C. T. (2010). Effects of dialogue journals on L2 students' writing fluency, reflections, anxiety, and motivation. Reflections on English Language Teaching, 9(2), 139-170.

Lukmantoro, T. (2000). Tingkat Kecemasan Komunikasi Mahasiswa Dalam Lingkup Akademis. Semarang: Universitas Diponegoro.

Powell. R.,\& Powell. D. (2010). Classroom Communication and Diversity. New York: Routledge.

Puspitasari, R. T. (2013). Adversity quotient dengan kecemasan mengerjakan skripsi pada mahasiswa. Jurnal Online Psikologi, 1(2).
Rosma, S. (2013). Pengaruh pelatihan berpikir positif untuk menurunkan kecemasan pada mahasiswa yang sedang menempuh skripsi. Jurnal Psikologi Universitas Ahmad Dahlan, 11-21.

Sellnow, D. (2005). Confident Public Speaking. Singapore: Wadsworth.

Silitonga, T. (2011). Fenomena komunikasi antarpribadi dosen pembimbing dan mahasiswa dalam bimbingan skripsi (Studi kasus kecemasan berkomunikasi dan ketidakpastian pada mahasiswa FISIP USU) (Skripsi, Universitas Sumatera Utara). 